\title{
The Concept of Defense Management in the 21st Century within Indonesia Maritime Security Framework
}

\author{
Herlina Juni Risma Saragih"1), Rayanda Barnas2), Deffi Ayu Puspito Sari ${ }^{3)}$ \\ 1) Lembaga Penelitian dan Pengabdian Masyarakat, Universitas Pertahanan, Bogor, \\ Indonesia \\ E-mail: herlinsara897@gmail.com \\ 2) Universitas Pertahanan, Indonesia \\ E-mail: bay.barnabas@yahoo.com \\ 3) Universitas Bakrie, Indonesia \\ E-mail: deffi.sari@bakrie.ac.id
}

\begin{abstract}
Conflict of Maritime Security in the Asia Pacific region, especially South China Sea is a conflict that has long occurred and a problem that is often raised both in a regional and international level. Related to the conflict takes Strategy and Management of the State's defense to anticipate the impact of the conflict situations on defense and security of the region. The purpose of this study is to analyze the concept of Defence Management Indonesia in the 21st century in the context of Indonesian Maritime Security, Case Studies U.S Rebalancing in Asia Pacific and South China Sea conflict, as well as to determine the readiness of Defence Management capabilities in the face of threats. The method used is a qualitative method of data collection methods through in-depth interview to the informant. The results showed that in order to improve maritime security in Indonesia has not been implemented in a structured and comprehensive defense in accordance with the management perspective of the countries more advanced, especially on defense preparedness in logistics management as a managing and defense equipment avaible owned by Indonesia government. Based on these results it is suggested the need for socialization implementation of Defense Management in Asia Pacific by Indonesia government in the context of Maritime Security comprehensively.
\end{abstract}

Keyword : Defense Management, US Rebalancing, Asia Pacific, South China Sea Dispute

\section{Introduction}

The South China Sea conflict is a long-standing conflict and is a frequently raised issue at the regional and global levels. There are six disputing countries in the South China Sea region, which are China, Taiwan, Vietnam, Malaysia, Philippines, and Brunei Darussalam. The conflict directly affects the economic, political, and security stability of the 
region. It also triggered the several other conflicts such as territorial dispute in the Spratly and Paracel Islands. The dispute is a central issue, not only for the countries in the region, but also for major countries with interests in the region, one of which is the United States. The United States knows that the dispute will potentially threaten the security in Asia-Pacific. Therefore, they decided to help resolve all peaceful settlement efforts. Each claimant state must follow the United Nations Conventions on The Law of The Sea (UNCLOS), agreed by the Association of Southeast Asian Nations (ASEAN) and China in 2002, in pursuing territorial claims (Tabloid Diplomasi, 2014).

In the last 20 months, the dynamics of the strategic environment in the South China Sea have been heating up, as China has reclaimed 7 islands. The conflict then expanded as the border dispute began to lead to Indonesian maritime territory, when there was an issue about China's claim over the Natuna Islands by including it in the nine-dash line on China's territorial map since 1974.

The Pentagon report says, since December 2013 China has reclaimed about 2,900 hectares of land in South China Sea, especially in Ferry Cross Reef. China then continues to do development in that area, such as the construction of airstrips, greenhouses, the deployment of 200 personnel of the People Liberation of Army (PLA) of China, as well as the construction of an airstrip that can accommodate H-6 bomber jets and Y-20 military transport aircraft.

Although Indonesia is not a claimant state, he Government of Indonesia must be firm against China. If diplomatic instruments are not accepted by China, then we must confront the military with China. To that end, the Government of Indonesia should immediately map out Indonesia's military and defense strategy in facing conflicts in South China Sea. According to Law No. 3 Year 2002 on State Defense, the President shall be responsible for formulating general defense policy to serve as a reference in the preparation, implementation, and supervision of defense systems by all elements of defense. Therefore, since August 25, 2015, President Joko Widodo (Jokowi) has enacted Presidential Regulation Number 97 Year 2015 as a substitute for Government Rgeulation Number 41 Year 2010 on General Defense Policy. Jokowi's general defense policy is aligned with the draft contained in the National Medium Term Development Plan 2015-2019 (RPJMN 2015-2019) and Defense Strategic Plan 2015-2019 (Renstra Pertahanan 2015-2019), which is also adapted to the strategic issues that are relevant to the improvement of defense capacity and the strengthening of national security stability. Such strategic issue can be attributed to conflicts in the border areas, namely security disturbances and violation of lawin border areas and integrative national security systems. But the strategic issue is still too macro and does not exactly ponting the South China Sea border dispute, specifically the issue of the claim of Natuna Islands by China.

In defense strategy and policy formulated by the Ministry of Defense, in accordance with 2010-2029 posture, the core of defense strategy and policy is directed to meet the Minimum Essential Force (MEF). MEF fulfillment policy is done in the form of budget enhancement, modernization of defense equipment, the development of defense posture and the addition of reserve component in all defense institutions, to keep the country's defense including in border area, like the Natuna Islands. However, until now, such defense planning has not yet been specifically targeted to protect Natuna Islands due tothe South China Sea conflict.

The "Maritime Axis" policy should be an effort to strengthen Indonesia's defense capabilities in marine areas and to counter any form of threat to Indonesian sovereignty. The escalation of the South China Sea conflict and the presence of the United States in the Asia- 
Pacific region are also a strong reason for Indonesia to strengthen its defence capabilities in the 21st century, especially from the maritime security sector.

Rear Admiral TNI (Ret.) Arsyad, as the mentor of the Institute for Maritime Studies Indonesia, said that in facing the SOuth China Sea conflict and the dynamics of the AsiaPacific region, the Indonesian government must demonstrate firmness in defending the country through concrete operational action, including naval diplomacy. In addition, the Indonesian government must also revolutionize defense strategy and management and the useof TNI force to face the new model of military threat and conventional warfare. Indonesia should also accelerate the change of defense posture in order to deal with conflicts in the South China Sea region. (Arsyad, 2016).

The statement before was also confirmed by the Head of The Indonesia Coast Guard (Badan Keamanan Laut Republik Indonesia/ BAKAMLA) Vice Admiral TNI Desi Albert Mamahit and Indonesian Defense Minister Ryamizard Ryacudu, who said that the South China Sea conflict is a real threat. Desi said that "South China Sea conflict is clearly a real threat to Indonesia" (Greater, 2014). Whereas the Indonesian Defence Minister stated that it is not safe to ignore the possibility of future threats, especially the situation seems to increase in recent months. Therefore, the development of military force is focused in the Natuna Islands region (Bhatnagar, 2016).

With the escalation of the South China Sea conflict, Indonesia is expected to make efforts to prepare itself to protect the sovereignty of the country if the conflict turns into a war. Therefore, this study focuses on the concept of Indonesian Defense Management in the 21st Century in order to address the United States rebalancing in the Asia-Pacific and South China Sea, with a primary focus on the defense management framework model. There are two research questions, which are:

1. How is the concept of defense management in Indonesia in the 21st century within the maritime security framework?

2. How is the readiness of Indonesia's defense management capability in the 21st century within the maritime security framework?

\section{Research Method}

This research is a qualitative research using qualitative descriptive research design. Qualitative descriptive design in this study was conducted in the form of case studies. There are two types of data source in this research, which are the primary and secondary data. Primary data source consists of direct observation in the field and interviews with specified sources. While the secondary data source is by literature study and literature. The subject of this research consists of officials and professionals. The objects of this research are the ability of defense management, the South China Sea conflict, and the dynamic in the Asia-Pacific region.

\section{Result and Discussion}

After the World War II, the United States was the sole power in the world, as well as a key actor in the Asia Pacific region. The rapid economic growth in China and India changed the constellation of world powers, as well as the region especially in the Asia Pacific region (Dormandy \& Kinane, 2014). China's rapid economic growth has changed the economic power of the region. Even the strength of China is currently mentioned growing rapidly along with the strength of the United States in the Asia Pacific region. The South China Sea conflict, located in the Asia Pacific region, should be anticipated to support regional security 
stability. Indonesia as a country in the Asia Pacific Region must have a good defense in preventing potential conflicts that may arise in the region.

Even though Indonesia is not a part of the South China Sea conflict, the escalation of conflict in the region is quite disturbing for Indonesia. Former Indonesian Defense Minister, Purnomo Yusgiantoro, said that Indonesia should be reasonable in response to the escalation of the conflict, but must prepare itself and improve its defense capability (Yusgiantoro, 2015).

\section{A. The Concept of Defense Management}

The improvement of defense management is not only to focus on the number of troops deployed according to the needs of the people, but to also focus on other things such as the readiness of troops in facing threats and defense equipments that support the effort to protect Indonesia from various threats. The change in Indonesian defense management into Military Operation Other Than War is an appropriate step to protect the territory of NKRI, considering Indonesia is not involved in the conflict.

The Indonesian government needs to step up efforts to improve defense management in the country. Defense Strategy and Policy is one of the concepts in defense management based on International Best Practices. Indonesia as a country that has strategic territory also has defense strategies and policies contained in the White Paper Defense.

\section{Defense Strategy and Policy}

Indonesia's Defense Strategy and Policy are designed to analyze environmental developments and strategic contexts in order to determine forecasts of threats, challenges, and risks to national defense. Currently, President Joko Widodo has introduce the concept of Global Maritime Axis, with the aim to make Indonesia's marine region as the world's strongest sea territory.

The development of defense strategy and policy to realize the Global Maritime Axis concept should be in line with the main objectives of the concept. The sea becomes the most vital part, but the air and the land are also sought to support the ability of the sea. If these three dimensions can be put together and work within the same framework, then this concept will be able to manifest itself well.

The Indonesian Government has made several efforts to make the Global Maritime Axis concept a reality, such as the addition of defense equipment to the manufacture of sea tolls to accelerate the economic growth of Indonesia. Going forward, the government socialize the concept more clearly, so there will be no confusion about the perception.

\section{Management of Defense Resources}

The management of defense resources is one of the important things for a country to maximize its potential, since not all countries have abundant natural resources. To achieve good and ideal defense management, a country is required to be able to manage its resources. The resources referred to in this study are all the wealth/ resources owned by a country to improve defense capability.

In the concept of the Global Maritime Axis, President Joko Widodo said that the Indonesian government will now focus on marine area by maximizing the wealth of marine resources. This is done by utilizing shipping areas, tourism, marine products, conservation areas, training rooms for the Navy and all potential uses of the sea.

This is in accordance with the concept of defense management regarding the management of natural resources. However, researchers see that the current resource management in Indonesia is not quite accurate, effective, and efficient. There are several factors that incfluence it, such as the human resources that are still not able to manage the 
existing resources, the lack of transparency about the amount of resources, and weak supervision and control on resource management.

\section{The Concept of Defence Human Resource Management}

Based on the material of Defense Human Resource Management conveyed by Mr. Aaron Taliafero, in order to achieve successin the performance of the task, a task force must reach a predetermined degree of preparedness. The level of unit readiness can be achieved if the unit is filled with the needs of its personnel according to the organizational structure of the unit. Personnel are educated and trained according to their positions and functions until they reach a defined level of competence. An integrated system of education and training between units will create a formidable defense performance.

Based from the result of the research, the Government of Indonesia has made various efforts to improve the capability of human resources in facing the challenges of defense. It is stated in Law Number 3 Year 2002 on State Defense that all citizens should be involved in the effort to organize the state defense. Thus, in dealing with the South China Sea conflict, the Indonesian government has made efforts to prepare itself in facing such threats. The desire to increase the number of troops in the Natuna Islands by one battalion is considered as an attempt to secure the territory of Indonesia.

The Indonesian government will increase troops in the Natuna Islands as many as 2000 personnel consisting of the Special Forces Corps of Indonesian Air Force (Korps Pasukan Khas/ PASKHAS), the Indonesian Marine Corps, and the Raider of Indonesian Army. The Minister of Defense said that Natuna would be guarded by one company of the Special Forces Corps of Indonesian Air Force, the Indonesian Marine Corps, and the Raider of Indonesian Army (Maharani, 2015). The Minister of Defense also said that up to now there are 18 units of Hawk 100/200 fighter aircraft in Lanud Supadio, Pontianak. In addition, the Indonesian Ministry of Defense also purchased several defense equipment such as air defectors (Maharani, Kemhan Tambah Alutsista Baru, 2015)

The Indonesian government considers that the escalation of the South China Sea conflict is something to be anticipated. Former TNI Commander Moeldoko, said that there will be an addition of one battalion of the Army, then the government will also improve the ability of the Indonesia Navy Base and Indonesia Air Force Base (Fiansyah \& Gatra, 2014). According to Moeldoko, the addition of troops is very important considering the maritime zone conflict can disrupt the sovereignty of Indonesia.

\section{Defense Logistic Management}

The concept of defense logistics management is a concept to meet or achieve the needs of military operations carried out by the military. This concept refers to the fulfillment of needs and the deployment of forces aimed at creating stable and secure conditions and to protect the territory of a country from various threats.

The development of Indonesian National Armed Forces (TNI) is based on the concept of capability-based defense, strength, and deployement of troops so that the development of TNI's main strength is directed to carry out the main task of upholding the sovereignty of the state, maintaining the integrity of the land territory and of saving the entire Indonesian nation which in its implementation is directed to the achievement of Minimum Essential Force.

In order to realize the development of the TNI's strength, budget support from the government is needed to achieve the stabilization of units that have the power of deterrence that is able to overcome any form of threat that may arise. Modernization of armaments is done gradually by implementing the replacement and procurement of new weapons in 
accordance with technological developments, as well as implementing the formation of new units in Indonesia, especially the border areas, conflict prone areas, outer islands as well as the whole region in accordance with the area and threat.

In relation with the South China Sea Conflicts, the Government of Indonesia has made some preparations; built the SU-27 Sukhoi base in 2014, AH-64E helicopters, added 1 infantry battalion, patrolled jet fighter squadron, also tens of warships from Navy's Western Fleet Command (Koarmabar) ready to deploy. Other preparation by The Indonesian Government such as building a type $\mathrm{C}$ airport in West Kalimantan that is useful to provide the operational needs which is held in the Natuna Islands region. Operations undertaken by the Government of Indonesia are not intended to create wars, but to anticipate threats that could disrupt the security stability of the region.

\section{Join Concepts dan Military Operations}

Join concept and military operation focus on cooperation between agencies to actualize the strategy and defense policy of a country. Inter-agency is expected to synergize in order to create a strong defense and protect the territory of the Republic of Indonesia from various threats. In this concept each brances has its own duty to perform its role in facing challenges and running the concept of maritime axis.

The research shows that there are several things that have been done by the Government of Indonesia, in this case Indonesian's Army, Air Force, and Navy, alongside civil institutions in carrying out its functions and responsibilities to face conflict in South China Sea. The operations, both strategic intelligence operations and joint operations continue to improve security in the Natuna Islands region. Efforts that have been made by the Government of Indonesia is to harmonize each agency to work together to manivest the vision and mission in facing the threats in South China Sea region.

The deployment of troop called military operations, involving the three branches of armed force and maximizing their functions. The Army performs a deployment of forces that serves to counter all kinds of threats that can occur in terrestrial areas. The Navy patrols the Natuna waters to encounter foreign ships entering Indonesian territorial waters illegally. While the Air Force is doing air defense patrols that are useful to increase alertness and deterrent action in case of threat from airspace .

Another effort to respond the South China Sea Conflict is to hold joint military exercises with the United States in the Natuna Islands. According to the Naval Spokesman, Manahan Simorangkir, this exercise is the second time, previously the exercise was held in Batam. In the first exercise, the main agenda is to drill the operation of patrol and supervisor aircraft. (Puspaningtyas, 2015).

The need for a joint operation plan for a more specific task is one of the pillars that supports and strengthens the capabilities of the military operations of each country. In the model, it can be seen that the Joint Concept Planning is built from the Strategy Model that is derived into the Mission Area, Objectives Readiness Requirements, so that Joint Concept Planning is obtained, as described in the following figure: 


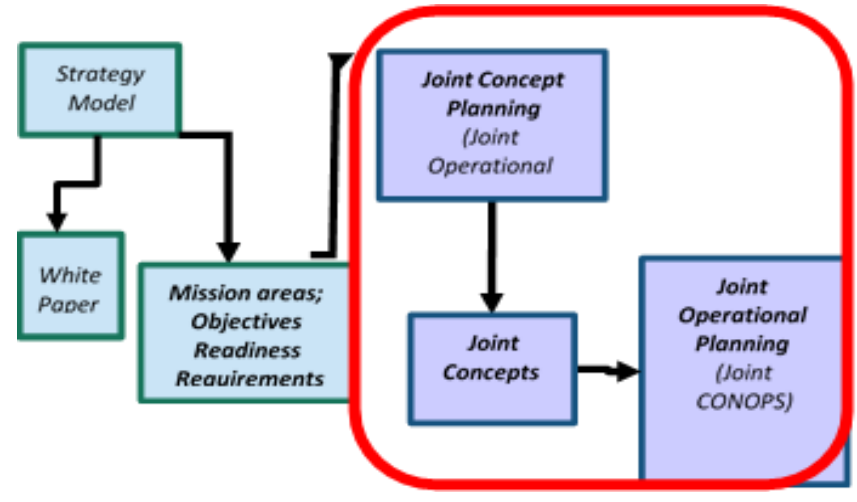

Figure 1. Joint Concept Planning

Join Concept Planning Military Operation in Indonesia itself includes MABES TNI issuing a command operation and supporting all the necessary needs of TNI in the implementation of the operation; Regional Command (Kodam) IM, I / BB, II / SWJ and XII / TPR carry out defense and security operations in their area of responsibility by deploying Army units in Natuna and Anambas District; Navy / Koarmabar conducts security and supervision of the sea to prevent territorial violation of a coastal region or coastal line or the use of sea communication in its territory, and quick and accurate action, by implementing the deployment of the Navy in accordance with the strategy of Navy Defense; And Airforce / Koopsau I and II carry out Air Operations in order to enforce sovereignty in its territory, by carrying out deterrence and prosecution in their respective areas including border areas And outer islands.

\section{B. Defense Management Readiness Concept}

Discussion of defense management readiness can be seen in military units. There are three main components in it; People, Equipment, and Readiness. These three components must be prepared in military and non-military operations.

\section{People}

In order to achieve quality human resources, the TNI is provided with education and training based on its position and function. Some efforts that have been made by the Indonesian government to improve the ability of Human Resources, among others, by improving the maintenance of personnel strength and ability by conducting pre-task exercises in accordance with applicable procedures which directed so that the personnel have the physical and mental readiness to carry out the operation.

\section{Equipment}

Indonesian Military Capability continues to increase significantly from the results of the military modernization program. Based on the data obtained by researchers, the number of defense equipment owned by Indonesia reached to $50 \%$, but the number is considered still not able to achieve all the needs of Indonesian defense equipment to deal with conflict.

\section{Readiness}

From the data, researchers have conducted research on the readiness of the Government of Indonesia in the face of the South China Sea Conflicts. The result is the readiness of the Government of Indonesia to reach 55\%. The figure is the sum total between 
personnel preparation and equipment. In addition it can be seen that the Government of Indonesia should accelerate the efforts to improve capability. If the Government of Indonesia continues to pursue the capabilities of the TNI in the Natuna Islands region, then the TNI can protect the Unitary State of Indonesia (NKRI) from various threats that disrupt the stability of national security

\section{Conclusion}

Based on the results of research and discussion in the previous chapter, the researchers gave a conclusion as follows:

a. Government of Indonesia implements state defense management including in border areas, particularly the Natuna issue due to the escalation of the South China Sea conflict and the presence of the United States in the Asia Pacific region. This is a strong reason for Indonesia to strengthen its defense capabilities in the 21st century, especially the maritime security to anticipate all possibilities that occur in the region.

b. The Indonesian Government's policy on Defense Strategy and Policy should focus on marine issues, according to President Jokowi's program which focus on maritime development. The policy should be an effort to strengthen Indonesia's defense capabilities in marine areas, as well as to counter any threats for the sovereignty of the Republic of Indonesia.

c. The MEF's policy-based defense capacity improvement model is carried out in the form of budget enhancement, modernization of defense equipment, the development of defense postures and the addition of reserve components across defense institutions.

d. The complexity of the problems occurring in the Asia Pacific and South China Sea Conflicts prompted the Government of Indonesia to immediately establish a policy related to the event to protect the territory of NKRI by designing strategies on Defense Management and Readiness of Indonesian Defense Management Capability in the 21st century.

\section{Reference}

Arsyad, R. (2016, Maret 04). Konflik Laut Cina Selatan. Retrieved from republica.co.id: republika.co.id

Bhatnagar, T. (2016, January 01). Mengapa Indonesia menambah Kekuatan Militer di Natuna? Retrieved from BBC Indonesia: http://www.bbc.com/indonesia/dunia/2015/12/151230_dunia_indonesia_natuna

Dormandy, X., \& Kinane, R. (2014). Asia-Pacific Security A Changing Role for The United States. London: Catham House The Royal Institute of International Affairs.

Fiansyah, R., \& Gatra, S. (2014, March 3). TNI Akan Tambah Pasukan untuk Jaga Laut Cina Selatan. Retrieved from Kompas.com: http://nasional.kompas.com/read/2014/03/03/1255252/TNI.Akan.Tambah.Pasukan.unt uk.Jaga.Laut.Cina.Selatan

Greater, J. (2014, October 2). RI Perkuat Pertahanan di Laut China Selatan. Retrieved from Jakarta Greayer: http://jakartagreater.com/ri-perkuat-pertahanan-di-laut-china-selatan/ Jakarta Greater. (2013, August 31). Indonesia dan Konflik Laut Cina Selatan. Retrieved from Jakarta Greater: http://jakartagreater.com/indonesia-dan-konflik-laut-china-selatan/ Jakarta Greater. (2014, Maret 31). Pembangunan Shelter Sukhoi di Natuna. Retrieved from Jakarta Greater: http://jakartagreater.com/pembangunan-shelter-sukhoi-di-natuna/ Jakarta Greater. (2014, December 8). Pesawat Tempur F-16 Disiagakan di Natuna. Retrieved 
from Jakarta Greater: http://jakartagreater.com/pesawat-tempur-f-16-disiagakan-dinatuna/

Maharani, E. (2015, September 16). Kemhan Tambah ALutsista Baru. Retrieved from NewsRepublika.co.id:

http://www.republika.co.id/berita/nasional/politik/15/09/16/nur1uw335-kemhantambah-alutsista-baru

Maharani, E. (2015, September 16). TNI Tambah 2000 Prajurit Jaga Natuna. Retrieved from NewsRepublika.co.id:http://nasional.republika.co.id/berita/nasional/politik/15/09/16/ nurcy2335-tni-tambah-2000-prajurit-jaga-natuna

Puspaningtyas, L. (2015, April 13). Menhan Ryamizard: TNI akan Tambah Pasukan di Natuna. Retrieved from NewsRepublika.co.id: http://nasional.republika.co.id/berita/nasional/daerah/15/04/13/nmqorz-menhanryamizard-tni-akan-tambah-pasukan-di-natuna

Schubert, S., \& Putill, J. (2015, May 18). US Marines begin arriving in Darwin in fourth rotation as part of US 'pivot' to the Asia-Pacific. Retrieved from abc.net.au: http://www.abc.net.au/news/2015-04-13/us-marines-arrive-darwin-us-pivot-amidconcern-tensions-china/6387444

SINDO. (2012, September 4). Hillary Dorong Persatuan ASEAN. Retrieved from SINDONews: http://international.sindonews.com/read/669767/42/hillary-dorongpersatuan-asean-1346722721

Tabloid Diplomasi. (2014). Kebebasan Bernavigasi. Retrieved from tabloiddiplomasi.org: www.tabloiddiplomasi.org

UNCED. (1992). Defining Capacity Building. Retrieved from http://www.gdrc.org/uem/capacity-define.html

Wardhana, E. (2013, December 17). AS peringatkan China soal penerapan zona pertahanan udara . Retrieved from SINDONews: http://international.sindonews.com/read/818054/42/as-peringatkan-china-soalpenerapan-zona-pertahanan-udara-1387297081

Yusgiantoro, P. (2015, August 26). Kemampuan TNI dalam Konflik Laut Cina Selatan. (F. Kuncoro, Interviewer) 